\title{
Penerapan Metode Prototyping Dalam Perancangan Interface Sistem Unggah Portofolio Penerimaan Mahasiswa Baru Diploma ISI Yogyakarta
}

\author{
Kathryn Widhiyanti ${ }^{1 *}$, Agnes Karina Pritha Atmani ${ }^{2}$ \\ ${ }^{1,2}$ Program Studi Animasi, Institut Seni Indonesia, DI Yogyakarta \\ Email: 1"kathryn@isi.ac.id, ${ }^{2}$ agneskarina@isi.ac.id
}

(Naskah masuk: 1 Nov 2020, direvisi: 10 Mei 2021, 14 Jun 2021, diterima: 15 Jun 2021)

\begin{abstract}
Abstrak
COVID 19 (Corona Virus Disease 2019) memberikan efek yang besar dalam bidang pendidikan, misalnya kegiatan belajarmengajar mengalami perubahan dari pertemuan kelas menjadi sistem daring yang memanfaatkan teknologi dan internet. Siswa, mahasiswa, orang tua, dan pendidik harus beradaptasi dengan metode pembelajaran daring. Sebagai salah satu instansi pendidikan di bidang seni, Institut Seni Indonesia (ISI) Yogyakarta juga merasakan efek dari pandemi COVID 19 ini. Selain kegiatan belajar mengajar, adaptasi yang cepat juga dilakukan pada proses Penerimaan Mahasiswa Baru (PMB) Program Diploma di jalur mandiri. Dalam kondisi COVID 19 ini, calon mahasiswa tentu juga akan terbatas untuk melaksanakan ujian secara langsung. Sistem Unggah Portofolio PMB Diploma dirancang untuk membantu calon mahasiswa supaya tetap dapat mendaftar ke ISI Yogyakarta dan tetap melanjutkan pendidikan untuk tingkat selanjutnya. Perancangan sistem unggah portofolio menggunakan metode prototyping dengan tujuan untuk mempercepat proses perancangan interface dan kinerja dari tim developer. Perancangan prototype menggunakan jenis Low Fidelity Prototype dan High Fidelity Prototype memberikan kemudahan komunikasi BAAKSI dan Tim Developer. Hasil usability testing yang diterapkan di akhir pengembangan memberikan hasil yang sangat baik yaitu antara 93\% -100\% untuk 5 kriteria yang diuji. Penerapan metode prototyping ini sangat sesuai diterapkan dalam proses perancangan sistem unggah portofolio yang hanya memiliki waktu developing singkat, namun dapat memberikan hasil rancangan interface yang optimal.
\end{abstract}

Kata Kunci: Antar Muka, Prototyping, Rapid Prototyping, Perancangan, Sistem Portofolio

\section{Application of the Prototyping Method in Designing the Upload System Interface for Diploma New Student Admissions ISI Yogyakarta}

\begin{abstract}
COVID 19 (Corona Virus Disease 2019) has a big effect in the field of education, for example teaching and learning activities have changed from class meetings to an online system that utilizes technology and the internet. Students, parents, as well as educators must adapt to online learning methods. As one of the educational institutions in the arts, the Indonesian Institute of Arts (ISI) Yogyakarta has also felt the effects of the COVID 19 pandemic. Apart from teaching and learning activities, rapid adaptation has also been made to the Diploma Program New Student Admissions (PMB) process on an independent path. In this COVID-19 condition, prospective students will of course also be limited to carrying out in-person exams. The PMB Diploma Portfolio Upload System is designed to help prospective students to still be able to register at ISI Yogyakarta and continue their education to the next level. The design of the portfolio upload system uses prototyping method with the aim of accelerating the interface design process and the performance of the developer team. The design of the prototype using the Low Fidelity Prototype and High Fidelity Prototype provides easy communication between BAAKSI and the Developer Team. The results of usability testing that were applied at the end of the development gave very good results, namely between $93 \%-100 \%$ for the 5 criteria tested. The application of this prototyping method is very suitable to be applied in the process of designing a portfolio upload system which only has a short developing time, but can provide optimal interface design results.
\end{abstract}

Keywords: Interface, Prototyping, Rapid Prototyping, Design, Portfolio System 


\section{PENDAHULUAN}

COVID 19 (Corona Virus Disease 2019) memberikan efek yang besar dalam bidang pendidikan misalnya kegiatan belajar-mengajar mengalami perubahan dari pertemuan kelas menjadi sistem daring yang memanfaatkan teknologi dan internet. Siswa, mahasiswa, orang tua, dan pendidik harus beradaptasi dengan metode pembelajaran daring. Institut Seni Indonesia (ISI) Yogyakarta sebagai salah satu instansi pendidikan di bidang seni, juga merasakan efek dari pandemi COVID 19 ini. Sistem perkuliahan daring di ISI Yogyakarta mampu diakomodir melalui LMS (Learning Management System) yang dimiliki oleh ISI Yogyakarta, melalui laman http://elearning.isi.ac.id.

Kebutuhan institusi yang tidak kalah mendesak pada masa pandemi selain proses perkuliahan, adalah Penerimaan Mahasiswa Baru (PMB) jalur Mandiri Program Diploma Tahun Akademik 2020/2021 di awal bulan Juni 2020. Perubahan tes praktek yang selama ini dilakukan dengan tatap muka (praktek dan wawancara), menjadi tes yang tidak membutuhkan tatap muka. Akan diwakili dengan sebuah sistem aplikasi secara daring. Calon mahasiswa peserta tes direncanakan dapat mengunggah semua dokumen audio visual portofolio yang mereka miliki untuk kemudian digunakan sebagai materi seleksi PMB jalur mandiri program Diploma ISI Yogyakarta di laman http://portofoliopmb.isi.ac.id. ISI Yogyakarta memiliki 3 Program Studi Diploma, yaitu Prodi D3 Batik dan Fashion, Prodi D4 Penyajian Musik, dan Prodi D3 Animasi.

Rumusan masalah dalam penelitian ini adalah mengakomodir kebutuhan Sistem PMB Jalur Mandiri Program Diploma dengan sebuah perancangan interface Sistem Unggah Portofolio yang mudah dipahami dan digunakan oleh bagian BAAKSI (Biro Administrasi Akademik, Kemahasiswaan, Perencanaan, dan Sistem Informasi) serta calon mahasiswa ISI Yogyakarta.

Metode Prototyping adalah metode yang dapat diterapkan pada perancangan ini, melihat situasi dan waktu yang ada untuk membuat Sistem Unggah Portofolio yaitu 15 hari dari awal hingga siap digunakan. Metode prototyping memiliki keunggulan untuk digunakan dalam perancangan dan pembuatan sistem dengan waktu sangat singkat. Dengan metode prototyping ini akan dihasilkan prototype sistem sebagai perantara pengembang dan pengguna agar dapat berinteraksi dalam proses kegiatan pengembangan sistem informasi [1].

Penerapan metode prototyping ini diharapkan dapat memberikan kemudahan dalam mengkomunikasikan dan memahamani perancangan sistem kepada para pengambil keputusan, yaitu pimpinan serta staf BAAKSI dan UPT PUSKOM (Unit Pelayanan Teknis Pusat Komputer) ISI Yogyakarta. Dengan proses analisis kebutuhan dan proses perancangan interface yang cepat tentu akan membantu tim developer untuk menghasilkan produk aplikasi sesuai dengan kebutuhan pengguna dan mudah untuk digunakan.

Pada penelitian sebelumnya menyebutkan bahwa, prototype dibuat dengan tujuan untuk memberikan kesamaan persepsi dan inisial pemahaman tentang proses dasar dari sistem yang akan dikembangkan, sehingga terjadi komunikasi yang baik antara pengembang dan pengguna sistem [2].

\section{METODOLOGI PENELITIAN}

\section{A. Metode Prototyping}

Metode perancangan interface yang digunakan dalam penelitian ini adalah prototyping. Prototyping dapat mempercepat proses perancangan dan pembuatan sebuah produk atau aplikasi [3]. Dalam metode ini pihak pengembang dan pengguna sistem informasi akan aktif berkomunikasi untuk menentukan kebutuhan dari interface yang akan dibuat. Gambar 1 merupakan diagram proses dari metode prototyping.

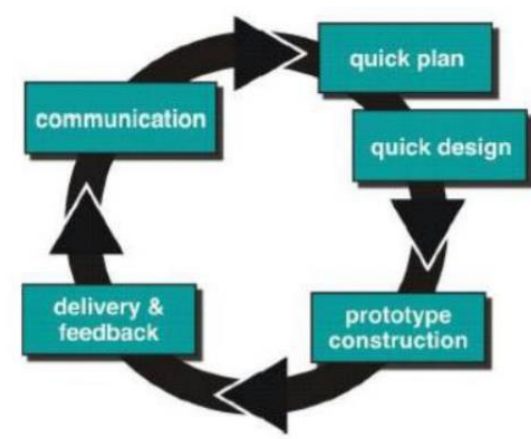

Gambar 1. Metode Prototyping [3]

Tahapan yang dilakukan dalam metode prototyping yaitu:

\section{Communication}

Komunikasi adalah proses berbagi informasi tentang desain, dan potensi penggunaannya dalam tim desain dan pengguna [4]. Pada tahap ini dilakukan komunikasi dengan user. User akan menceritakan fitur-fitur yang diperlukan dalam sistem ini serta ikut serta dalam memberikan evaluasi dan masukkan terhadap sistem yang sedang dikembangkan.

\section{Quick Plan and Quick Design}

Perencanaan yang cepat dan desain yang cepat merupakan ciri dari metode prototyping. Setelah mendapatkan data kebutuhan dari user. Pengembang akan melakukan perencanaan dan desain untuk sistem yang sedang dikembangkan.

\section{Prototype Construction}

Pembangunan prototype terjadi pada tahap ini. Pengembang akan membuat prototype yang dimulai dengan low fidelity prototype hingga high fidelity prototype. Desain prototype ini yang akan digunakan oleh user untuk memahami serta mengevaluasi apakah kebutuhan-kebutuhan yang diharapkan sudah terpenuhi.

\section{Delivery and feedback}

Tahap yang terakhir yaitu menyampaikan prototype ke pihak user untuk mendapatkan masukkan. Prototype akan 
memberikan gambaran secara visual kepada user atas sistem informasi yang akan dibangun. Dengan prototype ini, selain dari sisi fungsional, user juga dapat memberikan masukkan dari sisi desain interface.

\section{B. Low Fidelity Prototyping dan High Fidelity Prototyping}

Ada 2 kriteria prototype yaitu low-fidelity prototyping dan high-fidelity prototyping [5]. Low fidelity prototype merupakan prototype yang biasanya menggunakan media kertas, gambar tangan atau dengan software. Prototype jenis ini memiliki unsur interaktif yang rendah. Pengguna hanya bisa melihat gambaran aplikasinya namun belum dapat menggunakan secara interaktif.

High-fidelity prototyping merupakan prototype yang sudah mendekati bentuk aslinya. Prototype jenis ini juga memiliki ketepatan yang tinggi [6]. Pengguna dapat mencoba rancangan interface secara interaktif sehingga mendapatkan gambaran yang lebih tepat mengenai fungsi-fungsi serta estetika desainnya. Prototype jenis ini diharapkan dapat langsung diterapkan menjadi produk akhir.

\section{HASIL DAN PEMBAHASAN}

\section{A. Penerapan Metode Prototyping}

Metode prototyping memiliki 4 tahapan yang dilakukan terus-menerus sampai diperoleh interface yang sesuai dengan kebutuhan pengguna. Dalam penelitian ini terdapat 2 siklus perancangan prototyping yang dimulai dari analisis kebutuhan sampai interface dan sistem siap digunakan. Proses yang dilakukan yaitu:

\section{Siklus 1: Hand Sketch Prototyping \\ 1.1. Communication}

Komunikasi merupakan tahapan yang dilakukan untuk memperoleh data dari pengguna. Dalam perancangan interface Sistem Unggah Portofolio, komunikasi dilakukan dengan beberapa pihak yaitu Pembantu Rektor I, Kepala BAAKSI, dan Kepala UPT Puskom dalam sebuah Focus Group Discussion (FGD). Kegiatan FGD dilakukan untuk menggali kebutuhan data serta kebutuhan sistem unggah yang diharapkan oleh para user. BAAKSI mengharapkan sebuah sistem yang memiliki interface yang mudah dipahami, dan mampu mengakomodir/memfasilitasi unggah portofolio PMB jalur Mandiri Program Diploma. Diskusi dilakukan dengan berkunjung ke masing-masing unit kerja dengan menggali kebutuhan dan menawarkan/memberikan gambaran interface yang dibutuhkan. Hasil FGD yang telah dilakukan diperoleh kebutuhan para user, khususnya dari sisi admin BAAKSI dan calon peserta. Daftar kebutuhan untuk pengguna yaitu:

\section{Kebutuhan Administrator BAAKSI}

1) Admin dapat login

2) Admin dapat mengunggah data pendaftar yang diperoleh dari sistem pendaftaran yaitu file pendaftar dengan format Excel (*.xls)

3) Admin dapat melihat data pendaftar yang sudah diunggah.
4) Admin dapat mengubah data pendaftar.

5) Admin dapat mengunduh otomatis file portofolio dengan format *.pdf berdasarkan prodi.

6) Admin dapat mengunduh video portofolio dari halaman youtube, sistem aplikasi hanya memberikan link youtube yang diunggah oleh calon mahasiswa.

7) Admin dapat logout

\section{Kebutuhan Calon Mahasiswa}

1) Calon mahasiswa dapat login

2) Calon mahasiswa dapat melihat biodata singkat untuk memastikan login sesuai dengan akun calon mahasiswa.

3) Calon mahasiswa dapat mengunggah file portofolio dengan format *.pdf sesuai dengan ketentuan dari masingmasing prodi (D4 Penyajian Musik, D3 Batik dan Fashion, D3 Animasi)

4) Calon mahasiswa dapat menggungah link youtube untuk file video (D4 Penyajian Musik)

5) Calon mahasiswa dapat melihat hasil unggahan untuk file *.pdf.

6) Calon mahasiswa dapat logout.

\subsection{Quick Plan and Quick Design}

Setelah melalui proses communication dan didapatkan kebutuhan-kebutuhan pengguna yaitu admin BAAKSI dan calon mahasiswa, selanjutnya dilakukan tahapan perencanaan dan desain dengan proses cepat. Desain awal interface yang akan digunakan media komunikasi, untuk menyamakan persepsi mengenai fitur-fitur secara umum yang ada dalam Sistem Unggah Portofolio melalui kegiatan FGD dengan Staf BAAKSI. Gambar 2 merupakan perencanaan dan desain cepat yang dilakukan menggunakan hand skecth prototyping.

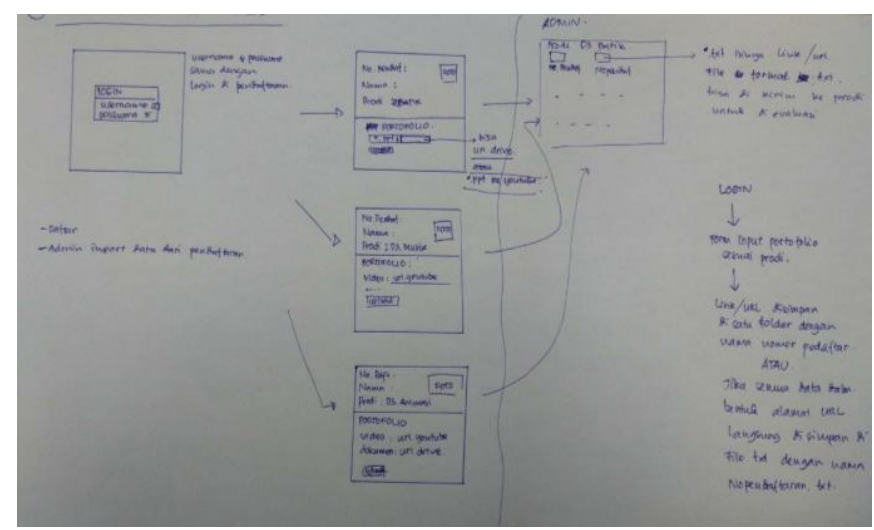

Gambar 2. Hand Sketch Prototyping ke-1 Sistem Unggah Portfolio

Pada FGD tahap ini, diperoleh hasil bahwa fitur-fitur yang ada sudah disetujui oleh BAAKSI, namun masih perlu penyesuaian dengan kebutuhan untuk masing-masing Program Studi.

\subsection{Prototype Construction}

Langkah selanjutnya yaitu dengan membuat rancangan prototype. Tahapan ini menggunakan hand sketch prototyping dengan fitur-fitur yang lebih lengkap dan disesuaikan dengan 
kebutuhan pengguna seperti terlihat pada Gambar 3, 4, dan 5. Prototype akan mendukung proses komunikasi supaya interface yang dibuat akan lebih user friendly karena akan melibatkan calon pengguna dalam menentukan desain dan fitur yang akan digunakan [7].

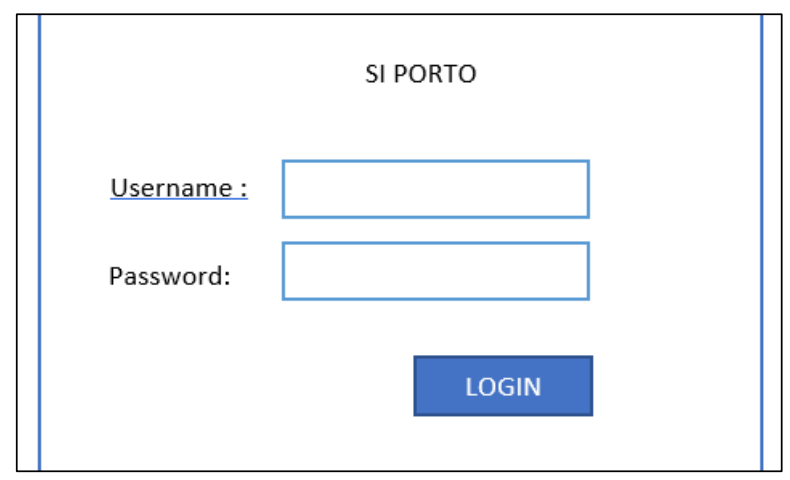

Gambar 3. Hand Sketch Prototyping ke-2 Sistem Unggah Portofolio "Halaman Login"

\begin{tabular}{|c|c|c|}
\hline SI PORTO & & LOGOUT \\
\hline Nama Camaba & \multirow{2}{*}{ DATA CAMABA } & \\
\hline \multirow{3}{*}{ Unggah Portofolio } & & \\
\hline & $\underline{\underline{\text { Nama: }}}$ & \\
\hline & Prodi: & \\
\hline \multirow[t]{2}{*}{ Lihat unggahan } & Fakultas: & \\
\hline & TTL: & \\
\hline & & \\
\hline & & \\
\hline
\end{tabular}

Gambar 4. Hand Sketch Prototyping ke-2 Sistem Unggah Portofolio "Halaman Data Calon Mahasiswa"

\begin{tabular}{|c|c|c|c|}
\hline SI PORTO & & & LOGOUT \\
\hline Nama Camaba & \multicolumn{3}{|l|}{ Unggah Portofolio } \\
\hline \multirow{4}{*}{$\begin{array}{l}\text { Unggah Portofolio } \\
\text { Lihat unggahan }\end{array}$} & \multicolumn{3}{|c|}{ Unggah file *.ppt berisi gambar sertifikat ...... } \\
\hline & Unggah & Lihat & \\
\hline & \multicolumn{3}{|c|}{ Unggah video presentasi } \\
\hline & Unggah & Lihat & \\
\hline
\end{tabular}

Gambar 5. Hand Sketch Prototyping ke-2 Sistem Unggah Portofolio "Halaman Unggah Portofolio"

\subsection{Delivery and Feedback}

Hasil hand sketch prototyping ke-2 langsung disampaikan ke BAAKSI untuk dievaluasi dan mendapatkan masukkan. Hand skecth prototyping ini membantu pihak BAAKSI untuk mendapatkan gambaran dari aplikasi yang diperlukan untuk proses unggah portofolio, sehingga dapat memberikan masukkan jika ada kebutuhan yang belum ada atau belum tersampaikan pada tahap sebelumnya.

Metode yang dilakukan dalam tahapan ini adalah dengan Focus Grup Discussion dengan BAAKSI. Hasil evaluasi yang diperoleh yaitu:

a. Desain awal bisa dipahami dan bisa dilanjutkan, kebutuhan inputan data dari sisi mahasiswa sudah terpenuhi, namun diperlukan penyempurnaan dari sisi desain.

b. Perlu diskusi dan riset mengenai detail kebutuhan masingmasing program studi agar data-data yang diinputkan sesuai dengan kebutuhan masing-masing program studi. Data dapat disesuaikan dengan soal yang disiapkan oleh program studi.

c. Dari sisi estetika, pihak BAAKSI tidak menentukan, yang utama sederhana saja agar dapat selesai dengan waktu yang cepat.

\section{Siklus 2: High-Fidelity Prototype}

\subsection{Communication}

Pada tahapan ini didapatkan informasi mengenai kelengkapan kebutuhan dari masing-masing prodi yaitu mengenai detil portofolio dan data yang harus diunggah oleh calon mahasiswa melalui soal atau syarat-syarat yang akan dipublikasikan kepada calon mahasiswa. Data-data yang perlu diunggah ternyata masih sama dengan syarat dokumen portofolio sebelum pandemi, sehingga tidak terjadi banyak perubahan desain dari sisi kebutuhan fungsional.

\subsection{Quick Plan and Quick Design}

Setelah mendapatkan informasi yang lengkap dari masing-masing program studi, maka dilakukan perbaharuan perancangan prototype yaitu high fidelity prototype. Pada rancangan ini sekaligus menambahkan sebuah fitur yaitu mengenai informasi soal atau syarat yang harus diunggah oleh mahasiswa berdasarkan program studi.

\subsection{Prototype Construction}

Prototype pada tahap ini, sudah tidak menggunakan hand sketch prototyping. Prototype langsung dibuat dalam bentuk yang interaktif, sehingga akan lebih memudahkan pengguna untuk memahami alur dari sistem yang dirancang. Prototype ini diharapkan dapat menjadi desain akhir yang dapat langsung diterapkan menjadi sebuah sistem yang utuh. 


\subsubsection{Interface Untuk Calon Mahasiswa}

\section{APLIKASIPORTOFOLIO}

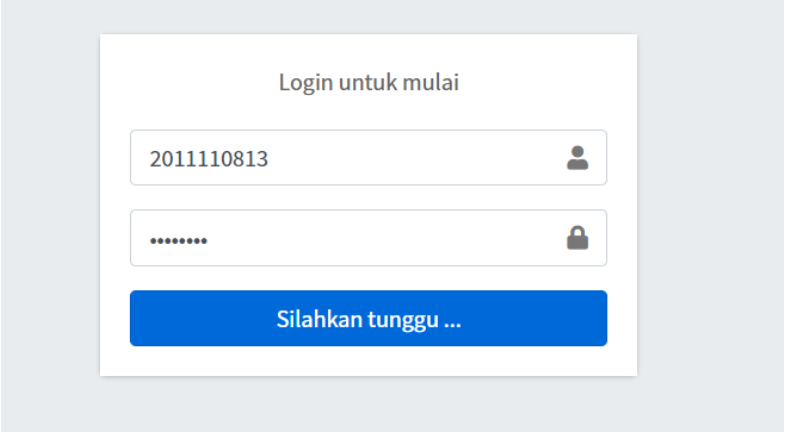

Gambar 6. Halaman Login Calon Mahasiswa

Calon mahasiswa terlebih dahulu melakukan login untuk menggunakan Sistem Unggah Protofolio seperti terlihat pada Gambar 6. Halaman login calon mahasiswa dan admin memiliki desain yang sama hanya dibedakan dengan warna tombolnya. Untuk calon mahasiswa memiliki tombol biru dan admin dengan warna merah.


Gambar 7. Beranda Sistem Unggah Portfolio

Halaman beranda ini berisikan mengenai data umum mahasiswa, data ini diperoleh dari data pendaftaran calon mahasiswa baru, seperti terlihat pada Gambar 7.
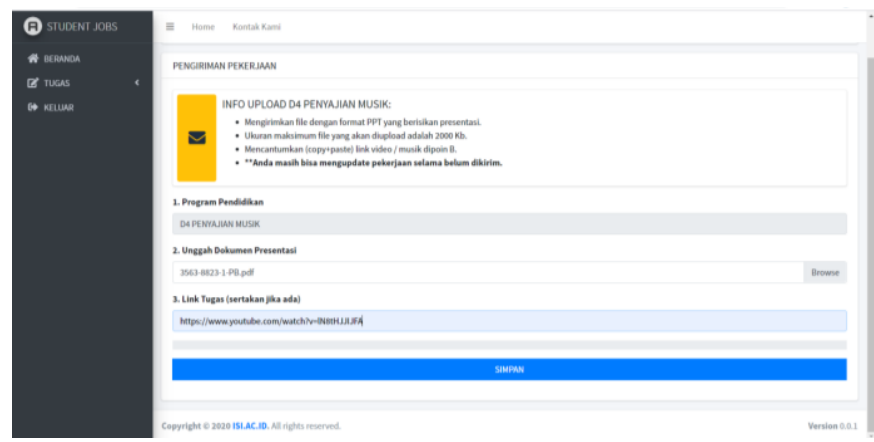

Gambar 8. Halaman Tugas Sistem Unggah Portofolio (1)

Pada halaman tugas ini (Gambar 8), mahasiswa mendapatkan informasi lengkap mengenai dokumendokumen yang harus diunggah serta maksimal besaran file.
Informasi tersebut berfungsi untuk mencegah terjadinya gagal unggah karena kesalahan tipe file atau kelebihan ukuran datanya. Mahasiswa dapat menggunggah dokumen presentasi dalam bentuk file *.ppt dan unggahan link video presentasi.
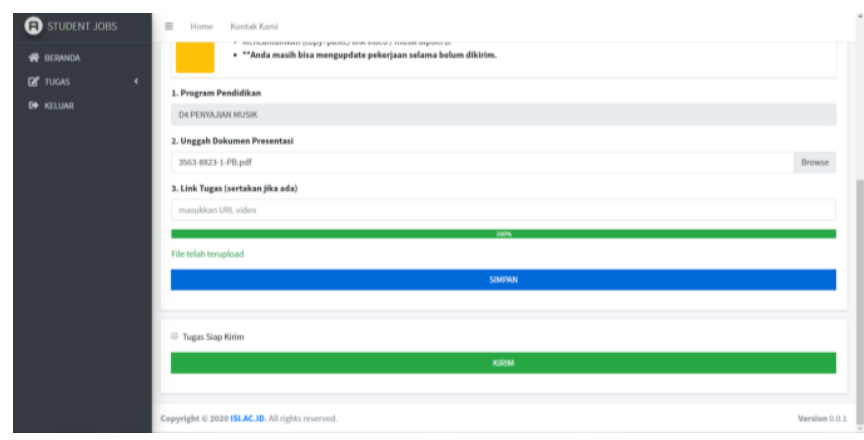

Gambar 9. Halaman Tugas Sistem Unggah Portofolio (2)

Masih dalam halaman yang sama yaitu halaman Tugas, Gambar 9 memperlihatkan kondisi calon mahasiswa sudah menyelesaikan unggahan dan dapat menyimpan file yang diunggah, kemudian mengirimkannya. Tombol simpan dan kirim tugas dirancang menjadi 2 tombol dengan tujuan saat dokumen baru disimpan saja artinya calon mahasiswa masih dapat mengulang unggah namun jika sudah menekan tombol kirim, artinya dokumen sudah tidak dapat diperbaharui. Warna tombol dibuat berbeda agar menjadi perhatian dari calon mahasiswa bahwa ada 2 tombol yang harus ditekan untuk menyelesaikan proses unggahan.
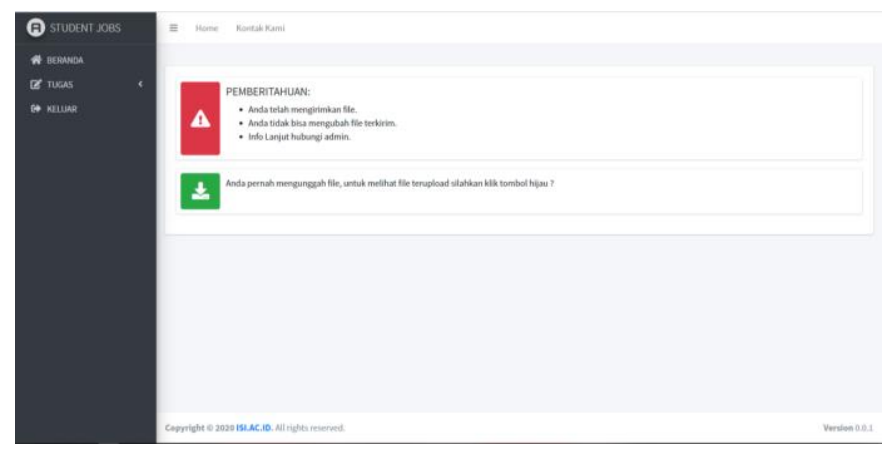

Gambar 10. Halaman Selesai Melakukan Unggah

Dokumen Sistem Unggah Portfolio

Kondisi calon mahasiswa yang sudah berhasil mengunggah dokumen dapat dilihat pada Gambar 10. Calon mahasiswa mendapatkan informasi bahwa sudah selesai mengunggah dan sudah tidak dapat mengunggah ulang. Pada informasi diberikan icon tanda seru dengan warna latar belakang merah dengan tujuan sebagai bentuk peringatan. Mahasiswa juga dapat menemukan icon download dengan warna hijau, artinya bahwa icon ini dapat diberikan aksi dengsn ditekan dan dapat melakukan fungsi unduh dokumen yang sudah diunggah. Tampilah dokumen yang sudah diunggah dapat dilihat pada Gambar 11. 


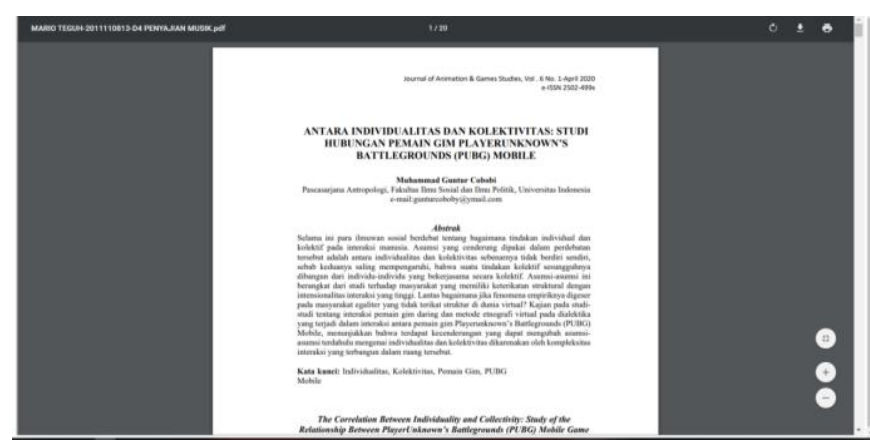

Gambar 11. File Dokumen yang Sudah Diuungah dan Dapat Diunduh

\subsubsection{Halaman untuk Admin}
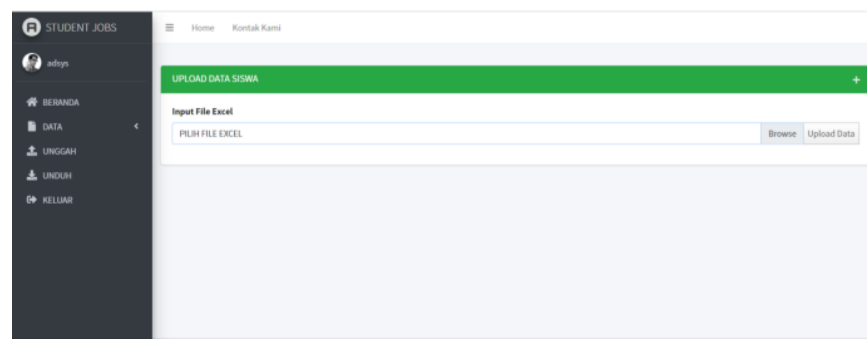

Gambar 12. Halaman Unggah Data Calon Mahasiswa

Admin melakukan unggah data calon mahasiswa dalam bentuk file Excel. Data berasal dari sistem pendaftaran mahasiswa baru. Pada Gambar 12, ditunjukkan ada 2 tombol untuk mencari data yang akan diunggah dan tombol untuk unggah. Tombol dirancang menjadi 2 fungsi terpisah untuk membantu pengguna yaitu admin BAAKSI dalam melakukan proses unggah data mahasiswa.
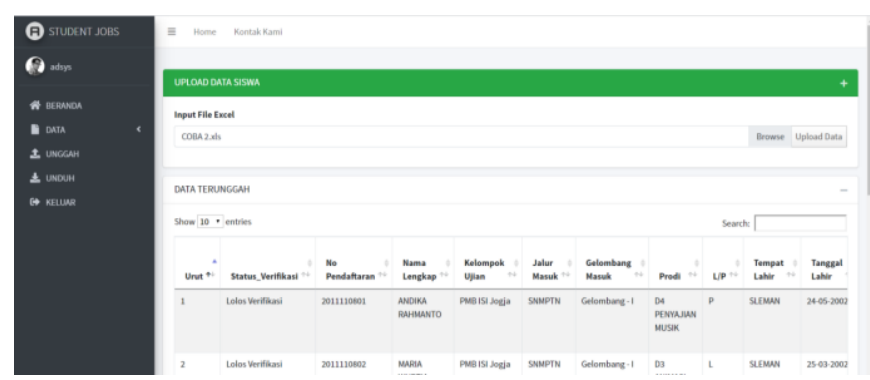

Gambar 13. Halaman Data Sudah Masuk ke Sistem

Setelah admin memilih file yang akan diunggah, sistem akan memunculkan data dari file (Gambar 13). Hal ini dilakukan agar admin BAAKSI dapat meneliti lagi apakah data yang diunggah sudah benar karena total jumlah pendaftar bisa mencapai ribuan, jika terjadi kesalahan input akan menjadi kesulitan untuk menemukannya. Apabila admin sudah yakin dengan data yang akan diunggah, admin dapat menekan tombol upload data dan data akan terunggah.



Gambar 14. Halaman Lihat Data Calon Mahasiswa

Admin dapat melihat data yang sudah diunggah pada menu lihat data seperti pada Gambar 14.

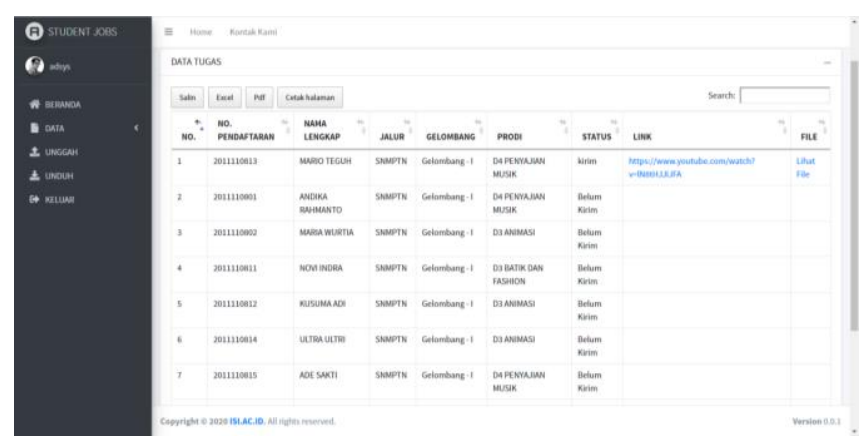

Gambar 15. Halaman Data Tugas

Admin dapat melihat unggahan dokumen mahasiswa pada halaman data tugas. Seperti yang terlihat pada Gambar 15, pada halaman data tugas terdapat informasi unggahan data yang belum terkirim dan yang sudah terkirim serta link dan dokumen yang dapat diunduh oleh admin BAAKSI.
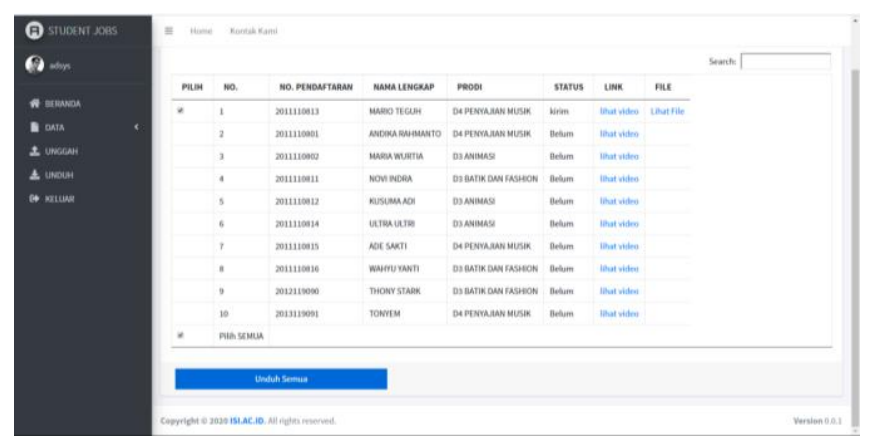

Gambar 16. Halaman Unduh Dokumen Unggahan

Admin BAAKSI dapat mengunduh dokumen yang telah diunggah oleh mahasiswa seperti pada Gambar 16. Proses mengunduh dapat dilakukan satu persatu atau dapat diunduh sekaligus.

\subsection{Delivery and feedback}

Setelah high fidelity prototype untuk calon mahasiswa jadi, maka disampaikan kepada pihak BAAKSI untuk mendapatkan evaluasi dan masukkan. Pihak BAAKSI dapat melakukan interaksi langsung pada prototype dan hasil dari evaluasi sudah sesuai dengan yang diharapkan. Semua fitur 
yang diperlukan baik dari sisi calon mahasiswa maupun admin BAAKSI sudah terpenuhi, namun diperlukan penyempurnaan lagi di beberapa bagian yaitu pada bagian identitas atau logo institusi serta penambahan menu verifikasi dari admin BAAKSI.

\section{Siklus 3: High-Fidelity Prototype (Revisi) \\ 3.1. Communication}

Masukkan dari prototype siklus ke 2 yaitu memunculkan identitas dan fitur verifikasi data unggahan dari admin BAAKSI sangat diperlukan serta merupakan komponen yang tidak boleh dilupakan. Identitas sebuah sistem informasi sangat diperlukan untuk membantu calon mahasiswa sudah berada di sistem yang benar yaitu Sistem Unggah Portofolio Institut Seni Indonesia Yogyakarta.

\subsection{Quick Plan and Quick Design}

Proses perancangan dilakukan dengan cepat dan sederhana yaitu menambahkan logo dan nama sistem dibagian atas untuk setiap halaman.

\subsection{Prototype Construction}


Gambar 17. Halaman Unduh Data Dengan Fitur Verifikasi

Halaman unduh data pada admin BAAKSI sudah memiliki fitur verifikasi sebagai penanda jika dokumen sudah lengkap dan sudah diunduh. Gambar 17 menunjukan bahwa sistem sudah memiliki identitas nama sistem dan institusi.yang juga ada pada setiap halaman.

\subsection{Delivery and Feedback}

Setelah keseluruhan desain interface diperbaiki, prototype interaktif ini diuji coba lagi oleh Admin BAAKSI dan mendapatkan keputusan bahwa semua kebutuhan sudah terpenuhi sehingga dapat digunakan sebagai desain interface akhir dan dilanjutkan proses developing fungsionalnya. Selanjutnya Sistem Unggah Portofolio PMB Diploma ISI Yogyakarta akan diunggah pada alamat http://portofoliopmb.isi.ac.id.

\section{Evaluasi Usability}

Setelah prototype interface Sistem Unggah Portofolio PMB Diploma ISI Yogyakarta selesai dirancang, proses dilanjutkan dengan developing secara keseluruhan dan akan dilakukan evaluasi kembali untuk mendapatkan hasil rancangan yang optimal. Metode evaluasi yang digunakan dalam pengujian akhir ini adalah Usability Testing atau uji kebergunaan. Uji kebergunaan adalah pengujian efisiensi, kemudahan dipelajari, dan kemampuan untuk mengingat bagaimana berinteraksi tanpa kesulitan atau kesalahan [8]. Kriteria yang akan diuji yaitu kemudahan dipelajari, efisiensi, mudah untuk diingat, tingkat kesalahan yang minimal dan kepuasan pengguna dari aplikasi ini. Pengujian ini dilakukan dengan pengguna yaitu karyawan BAAKSI sebanyak 5 orang, karyawan PUSKOM sebanyak 2 orang, perwakilan karyawan program studi 3 orang, dan perwakilan mahasiswa program studi angkatan 2019 sebanyak 6 orang. Karyawan yang mengevaluasi adalah karyawan yang akan terlibat dalam proses penerimaan mahasiswa baru, namun tidak dilibatkan dalam perancangan interface.

Proses pengujian yaitu dengan memberikan beberapa tugas seperti yang ada pada Tabel 1. Tugas akan diselesaikan oleh masing-masing responden dan kemudian responden akan memberikan masukkan mengenai 5 komponen usability testing.

Tabel 1. Daftar Tugas Evaluasi Usability Testing

\begin{tabular}{|l|l|}
\hline \multicolumn{1}{|c|}{ Bagian Uji } & \multicolumn{1}{c|}{ Tugas } \\
\hline Halaman Admin & Login \\
\cline { 2 - 2 } & mengunggah data pendaftar \\
\cline { 2 - 2 } melihat data pendaftar \\
\cline { 2 - 3 } Malaman Calon & mengubah data pendaftar \\
\cline { 2 - 2 } & mengunduh file portofolio \\
\cline { 2 - 2 } & Logout \\
\cline { 2 - 2 } & Login \\
\cline { 2 - 2 } & $\begin{array}{l}\text { Melihat Biodata } \\
\text { portofolio }\end{array}$ \\
\cline { 2 - 2 } & Mengunggah file portofolio (*.pdf) \\
\cline { 2 - 2 } & Menggunggah video portofolio \\
\cline { 2 - 2 } & Melihat hasil unggah portofolio \\
\hline
\end{tabular}

Dari hasil evaluasi yang dilakukan diperoleh prosentase dari masing-masing komponen usability testing seperti pada Tabel 2. Nilai persentase diperoleh dengan membandingkan hasil penyelesaian tugas serta pendapat dari responden mengenai 5 kriteria uji dengan total jumlah responden. Sedangkan untuk klasifikasi prosentase uji dikelompokan menjadi 3 yaitu Sangat baik (80\% - 100\%), Baik (60\%-79\%), cukup baik (40\%-59\%), kurang baik $(20 \%-39 \%)$ dan sangat tidak baik $(<19 \%)$ [9].

Tabel 2. Hasil Usability Testing

\begin{tabular}{|l|r|l|}
\hline \multicolumn{1}{|c|}{ Kriteria Uji } & Prosentase & Keterangan \\
\hline Learnability & $93 \%$ & Sangat baik \\
\hline Efficiency & $100 \%$ & Sangat baik \\
\hline Memorability & $100 \%$ & Sangat baik \\
\hline Error & $93 \%$ & Sangat baik \\
\hline Satisfaction & $100 \%$ & Sangat baik \\
\hline
\end{tabular}

Secara keseluruhan desain interface Sistem Unggah Portofolio PMB Diploma ISI Yogyakarta memiliki kualitas yang sangat baik. Kemampuan untuk dipelajari (learnability) dan minimalisasi kesalahan (errors) memiliki nilai 93\% 
karena ada 1 orang responden yang sempat mengalami kesulitan memahami alur penggunaan sistem saat pertama kalinya.

Untuk kriteria uji efficiency, kemampuan untuk diingat (memorability) mendapatkan angka $100 \%$ karena untuk bagian calon mahasiswa hanya ada 2 menu yaitu lihat data calon mahasiswa dan unggah portofolio, sehingga dalam satu halaman mahasiswa sudah dapat menyelesaikan unggahan portofolionya. Selain itu, untuk perancangan langkah dan desain icon-icon, tombol-tombolnya yang sederhana dan berwarna sehingga sangat terlihat perbedaan untuk masingmasing icon. Hal tersebut menjadi memudahkan pengguna untuk mengingat fungsi tombol dan icon yang ada.

Secara keseluruhan, responden memberikan penilaian $100 \%$ puas dengan rancangan interface dari Sistem Unggah Portofolio PMB Diploma ISI Yogyakarta. Sistem ini dapat dipublikasikan dan dimanfaatkan oleh unit BAAKSI serta calon mahasiswa baru untuk melakukan pendaftaran dan seleksi.

\section{KESIMPULAN DAN REKOMENDASI}

Metode prototyping sangat sesuai untuk diterapkan dalam perancangan interface sistem unggah portofolio PMB Diploma ISI Yogyakarta, karena diperlukan perancangan dan pembuatan aplikasi dengan waktu yang cepat dan tentu saja harus memenuhi kebutuhan pengguna. Prototype yang digunakan baik dalam low-fidelity prototype maupun high fidelity prototype membantu dalam berkomunikasi dengan pihak BAAKSI sebagai pengguna sistem untuk menentukan kebutuhan yang tepat. Proses evaluasi dan pemberikan feedback dari pihak BAAKSI juga dapat berjalan dengan cepat dan tepat karena adanya prototype yang memiliki visual mendekati rancangan akhir. Pada hasil usability testing yang dilakukan ketika sistem sudah selesai dibuat secara keseluruhan juga menunjukkan hasil yang sangat baik untuk yaitu antara $93 \%-100 \%$.

Rekomendasi untuk tahap selanjutnya adalah sistem ini dapat dikembangkan lagi tentunya dengan perancangan yang lebih detil mengenai kebutuhan seleksi penerimaan mahasiswa baru jalur mandiri baik Diploma maupun untuk Strata 1. Kebutuhan untuk tim penilai dapat langsung menilai di sistem juga dapat ditambahkan dalam pengembangan selanjutnya.

\section{REFERENSI}

[1] Purnomo, D. (2017). Model Prototyping Pada Pengembangan Sistem Informasi. Jurnal Informatika Merdeka Pasuruan, Vol. 2(2), pp. 54-61, DOI: 10.37438/jimp.v2i2.67.

[2] Susanto, A. \& Meiryani. (2019). System Development Method with The Prototype Method. International Journal of Scientific \& Technology Research, Vol. 8(7), pp. 141-144.

[3] Pressman, R.S. \& Maxim, B. (2015). Software Engineering A Practitioner's Approach. New York: Mc Graw Hill Education.

[4] Camburn, B., Viswanathan, V., Linsey, J., Anderson, D., Jensen, D., Crawford, R., Otto, K. \& Wood, K. (2017). Design Prototyping Methods: State of the Art in Strategies, Techniques, and Guidelines. Design Science, Vol. 3(13), pp. 1-33, DOI: 10.1017/dsj.2017.10.

[5] Sharp, H., Preece, J. \& Rogers, Y. (2015). Interaction Design: Beyond Human Computer Interaction, 4th Edition. England: John-Wiley \& Sons.

[6] Santi, R.C.N. (2016). Perancangan Interaksi Pengguna (User Interaction Design) Menggunakan Metode Prototyping. Jurnal Teknik Informatika, Vol. 9(2), pp. 108-113, DOI: 10.15408/jti.v9i2.5599.

[7] Ammash, A.H., Sutjiadi, R. \& Pattiasina, T.J. (2017). Analisa dan Perancangan Website Media Sosial Untuk Komunitas Tari Dengan Metode Prototyping. Teknika, Vol. 6(1), pp. 24-34, DOI: 10.34148/teknika.v6i1.61.

[8] Aries, T.M., Ranius, Y.A. \& Saputri, N.A. (2017). Usability Testing Untuk Mengukur Penggunaan Website STIK Bina Husada Palembang. Jurnal Teknik Informatika, pp. 1-12.

[9] Sugiyono. (2015). Metode Penelitian Kuantitatif Kualitatif dan $R \& D$. Bandung: Alfabeta. 